\title{
Influence of Chemical Thinning on Plum Fruit Weight and Diameter
}

\author{
Andreea Flavia TRIPON ${ }^{1 *}$, Viorel MITRE ${ }^{1}$, Ioana MITRE ${ }^{1}$, Ioana MITRE Jr. ${ }^{1}$, Tabita LISANDRU ${ }^{1}$, Monica \\ PAL $^{1}$
}

${ }^{1}$ Department of Fruit growing, University of Agricultural Sciences and Veterinary Medicine, ClujNapoca, Romania

*)Corresponding author, e-mail: andreeaflavia_tripon@yahoo.com

BulletinUASVM Horticulture 73(2) / 2016

Print ISSN 1843-5254, Electronic ISSN 1843-5394

DOI:10.15835/buasvmcn-hort:11953

\begin{abstract}
Fruit quality is becoming of a great importance due to the consumers increasing demand for high quality plums. The quality of the fruits is highly influenced by the morphological and organoleptic characteristics of the fruit (shape, size, background color and coverage, color and consistency of the pulp, juiciness, taste, flavor, etc.), as well as technological, biochemical and nutritional value of them. Fruit size is expressed mostly by the fruit weight and diameter. The current study took place in two fruit tree plantations: Călacea from Sălaj County and Agroindustriala orchard from Cluj-Napoca. During the experiment 7 plum cultivars were analyzed. Determinations regarding the influence of thinning have been made for these cultivars on fruit weight (g) and fruit diameter ( $\mathrm{mm}$ ). Following the chemical treatments for thinning, the highest percentage of fruit with a diameter bigger than 35 mm, in fruit-growing ecosystem Călacea-Sălaj County, was obtained for Stanley cultivar, after the treatment with Cosavet, while in Cluj-Napoca at the Agroindustriala orchard, the highest percentage of fruit with a diameter bigger than $35 \mathrm{~mm}$ was obtained also for Stanley cultivar, but after the treatment with Ethrel. The highest fruit weight value was recorded for Stanley variety in Călacea, after applying the treatment with Cosavet products $(60.2 \mathrm{~g})$, Sulfomat (49.6 g) and Ethrel (48.28 g); in Cluj-Napoca, the highest value of fruit weight was recorded for Nectarină Roșie variety, after the treatment with Cosavet products (57.8 g) and Sulphur (57.8 g).
\end{abstract}

Keywords: diameter, flowers, fruits, quality, thinning

\section{Introduction}

The quality of plum fruit is a very complex feature, as well as productivity, depending both on the hereditary basis of the cultivars and the environmental conditions (Ardelean et al., 2006). For tree farming research and for fruit producers, the increase of fruit production and quality are essential objectives. Thinning may influence both of them, thus, it is a very important part in the technological chain (Wilkie et al., 2008).

\section{Aims and objectives}

The aim of this study was to investigate the influence of thinning on fruit diameter and weight, in two different locations.

\section{Materials and methods}

The experiment was carried out between 2012 and 2014. The research took place in two different orchards, in different locations: CălaceaSălaj County and Agroindustriala-Cluj-Napoca, where 7 plum cultivars were investigated. Determinations regarding the influence of thinning have been made for these cultivars on fruit weight ( $\mathrm{g}$ ) and fruit diameter (mm). Chemical thinning was applied to flowers when $80 \%$ of them were already open, with the following products: Ethrel, 0.01\% concentration, Cosavet 80 DF, Sulphur 80 WG and Sulfomat $80 \mathrm{PU}$, all three with the concentration of $5 \%$. From each variety 100 fruits were harvested and analyzed. The data was analyzes using ANOVA Test. 


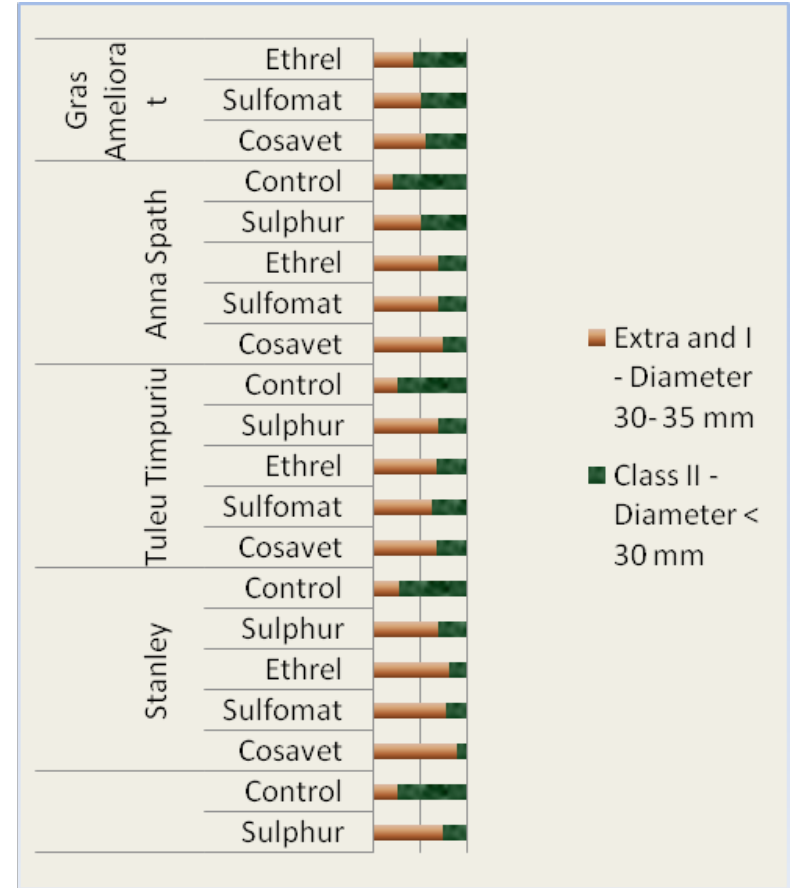

$1 a$

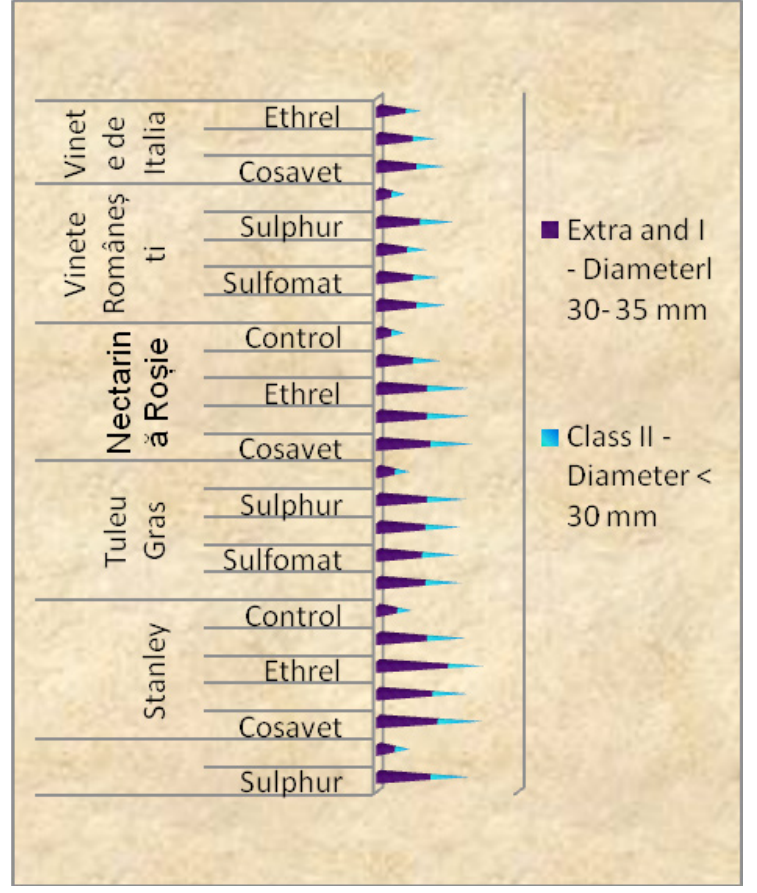

1b

Fig.1. The influence of chemical thinning on fruit diameter of the studied plum cultivars

\section{Results and Discussion}

The results of the research show that the highest percentage of fruit with a diameter bigger than $35 \mathrm{~mm}$ was obtained for Stanley cultivar, after the treatment applied with Ethrel (90\%) in Călacea orchard (Fig. 1a) whereas the highest percentage of fruit diameter bigger than $35 \mathrm{~mm}$ was obtained for Stanley cultivar, after the treatment with Cosavet (85\%) in the Agroindustriala orchard (Fig. 1b).

It can be noted that regardless the treatment, in Călacea orchard the highest value of fruit weight $(\mathrm{g})$ was registered in the case of Stanley variety after the treatment with Cosavet products (60.2 g), Sulfomat (49.6 g) and Ethrel (48.28 g) applied. Nevertheless at Agroindustriala orchard, the highest value for fruit weight was obtained in Nectarină Roșie variety after the treatment with
Cosavet products (57.8 g) and Sulphur (57.8 g) applied.

\section{Conclusion}

Analysing the results obtained due to this experiment, it has been found that the fruit weight and diameter are notably influenced by chemical thinning; therefore it is recommended to apply chemical thinning in the orchards to improve fruit quality.

\section{REFERENCES}

1. Ardelean M, Sestraș R and Cordea M (2006). Horticultural plant breeding, Ed. AcademicPres, Cluj-Napoca.

2. Wilkie JD, Sedgley M and Olesen T (2008). Regulation of floral initiation in horticultural trees, J Exp Bot 59:12, 3215-3228. 